\title{
Late outcome after pylorus preserving pancreaticoduodenectomy for ampullary carcinoma following severe acute post-stenting pancreatitis: case report and review of the literature
}

\author{
Odległe wyniki leczenia po pankreatoduodenektomii z zaoszczędzeniem \\ odźwiernika u chorych na raka brodawki Vatera po przedoperacyjnym \\ protezowaniu dróg żółciowych powikłanym ciężkim, ostrym zapaleniem \\ trzustki - opis przypadku i przegląd piśmiennictwa
}

\author{
Magdalena Skórzewska, Wojciech P. Polkowski \\ Department of Surgical Oncology, Medical University of Lublin, Poland
}

Przegląd Gastroenterologiczny 2011; 6 (6): 411-414 DOI: $10.5114 / p g .2011 .25998$

Key words: ampullary carcinoma, biliary stenting, acute pancreatitis, pylorus preserving pancreaticoduodenectomy, complications. Słowa kluczowe: rak brodawki Vatera, protezowanie dróg żółciowych, ostre zapalenie trzustki, pankreatoduodenektomia z zaoszcządzeniem odźwiernika, powikłania.

Address for correspondence: Wojciech P. Polkowski MD, PhD, Department of Surgical Oncology, Medical University of Lublin, 11 Staszica, 20-081 Lublin, Poland, phone: +48 815344 313, fax: +48 81532 23 95, e-mail: wojciech.polkowski@am.lublin.pl

\begin{abstract}
Patients undergoing endoscopic retrograde cholangiopancreatography (ERCP) should have stenting of the biliary system to prevent cholangitis. However, the most serious complication of ERCP is pancreatitis. There are only scattered data on the impact of post-ERCP pancreatitis on the surgical management of periampullary tumours. We report the case of a patient with carcinoma of the ampulla of Vater who underwent preoperative biliary stenting complicated with severe acute pancreatitis and was effectively treated by pylorus preserving pancreaticoduodenectomy (PD) 3 months later. In the postoperative course, grade A pancreatic fistula was observed, with no substantial prolongation of hospital stay. Pathological findings revealed stage II ampullary carcinoma with multiple foci of pancreatic necrosis. Three weeks after the procedure, the patient fully recovered, and started adjuvant chemotherapy. Disease free survival DFS was 27 months and OS 44 months. Pancreaticoduodenectomy can be performed after severe acute necrotizing pancreatitis caused by preoperative biliary stenting, provided adequate timing of surgery is ensured, albeit with the risk of postoperative complications. Even severe post-ERCP pancreatitis should not be regarded as a contraindication for curative PD, especially in patients with periampullary adenocarcinoma, since long-term survival can be achieved.
\end{abstract}

\section{Streszczenie}

Pacjenci poddawani endoskopowej cholangiopankreatografii wstecznej (ECPW) powinni mieć wykonywane protezowanie dróg żółciowych, aby zapobiec zapaleniu dróg żółciowych. Najpoważniejszym jednak powikłaniem po ECPW jest zapalenie trzustki. Dane z piśmiennictwa na temat wpływu zapalenia trzustki po ECPW na postępowanie chirurgiczne $u$ chorych na raka brodawki Vatera są niepełne. Autorzy przedstawiają chorą na raka brodawki Vatera, u której powikłaniem przedoperacyjnego protezowania dróg żółciowych było ciężkie, ostre zapalenie trzustki, które skutecznie leczono wykonaną 3 miesiące później pankreatoduodenektomią (PD) z zachowaniem odźwiernika. W przebiegu pooperacyjnym zaobserwowano wystąpienie przetoki trzustkowej (w stopniu A), bez wpływu na czas hospitalizacji. Wynik badania histopatologicznego potwierdzit rozpoznanie raka brodawki Vatera w stadium II z licznymi ogniskami martwicy w obrębie trzustki. Trzy tygodnie po zabiegu pacjentka zakończyła rekonwalescencję pooperacyjną i rozpoczęła chemioterapię uzupełniającą. Przeżycie wolne od objawów choroby wyniosło 27 miesięcy, a przeżycie całkowite 44 miesiące. Pankreatoduodenektomia może być wykonana po ciężkim, ostrym zapaleniu trzustki spowodowanym endoskopowym protezowaniem dróg żółciowych, pod warunkiem podjęcia decyzji o operacji w odpowiednim czasie, z uwzględnieniem ryzyka wystąpienia powikłań pooperacyjnych. Nawet ciężkie zapalenie trzustki po ERCP nie powinno być traktowane jako przeciwwskazanie do PD z zamiarem wyleczenia, zwłaszcza u chorych na gruczolakoraka brodawki Vatera, ponieważ stwarza nadzieję na dobry wynik odległy. 


\section{Introduction}

Endoscopic retrograde cholangiopancreatography (ERCP) is a useful tool in evaluating biliary, ampullary and pancreatic ductal anatomy in patients who require either diagnosis or palliation. While the role of routine preoperative biliary stenting of patients who undergo pancreaticoduodenectomy (PD) is controversial, it is clear that patients undergoing ERCP should have stenting of the biliary system to prevent the sequelae of cholangitis.

One possible cause of an acute, even severe necrotic form of pancreatitis may be the ERCP procedure itself, so-called post-ERCP pancreatitis. The anticipated rate of post-ERCP pancreatitis ranges from $1 \%$ to $7 \%$ according to data reviewed by the Standards of Practice Committee of the American Society of Gastrointestinal Endoscopy [1]. In patients with suspected sphincter of Oddi dysfunction undergoing sphincter of Oddi manometry, the risk is up to $25 \%$ [2]. Unfortunately, despite years of research involving the search for a medication or technique that can reliably decrease the risk of postERCP pancreatitis, no clear solution has been found.

The first surgical resection of the ampulla of Vater was performed by Halsted in 1899. Local excision for patients with $\mathrm{T} 1$ carcinomas has been advocated by some; however, the question of incomplete tissue resection remains. It has also been suggested that up to $10 \%$ of patients with $\mathrm{T} 1$ lesions will have local lymph node involvement. For this reason, many groups prefer to perform PD, either the classic Whipple resection or the pyloric sparing procedure. Pylorus preserving pancreaticoduodenectomy (PPPD), in which the antrum and pylorus of the stomach are preserved, is routinely applied by many surgeons, as there is limited oncological value of resection of the antrum. It is believed that preservation of the antrum may lead to better overall long-term function, although this has not been demonstrated in prospective randomized trials. Morbidity associated with the procedure remains substantial, ranging from $25 \%$ to $50 \%$ [3]. Pylorus preserving pancreaticoduodenectomy is a specialized procedure best performed by those individual surgeons or groups that have sufficient experience and volume to assure satisfactory outcomes. In 2000, both the median postoperative stay declined over time to 8 days and perioperative mortality decreased to $1 \%$ [4]. Median survival after resection for carcinoma of the ampulla of Vater is 24 months with $43 \%$ 5-year survival [5].

Carcinoma of the ampulla of Vater has a higher resectability rate and a much better survival rate than pancreatic cancer. Pancreaticoduodenectomy is the treatment of choice for this tumour. However, in severe necrotizing acute (post-ERCP) pancreatitis, immediate PD is not indicated as it is associated with high mortality rates, as well as increased risk of postoperative exocrine and endocrine insufficiency [6]. There are only scattered data on the impact of post-ERCP pancreatitis associated with preoperative biliary stenting on the surgical management of periampullary tumours, as well as late outcome.

We report the case of a patient with carcinoma of the ampulla of Vater who underwent preoperative biliary stenting complicated with severe acute pancreatitis and was subsequently treated by PD with long-term follow-up.

\section{Case report}

A 59-year-old female patient with jaundice (serum bilirubin level: $10.8 \mathrm{mg} / \mathrm{dl}$ ) due to ampullary carcinoma was initially treated by preoperative biliary stenting. After the endoscopic procedure utilizing a plastic stent, she developed the severe form of acute pancreatitis (serum amylase $514 \mathrm{IU} / \mathrm{l}$ ). Thereafter, the patient was hospitalized in the intensive care unit (ICU) for 3 weeks and treated medically for pancreatitis. After 3 months, both serum bilirubin and C-reactive protein (CRP) levels returned to normal values: $0.3 \mathrm{mg} / \mathrm{dl}$ and $2.2 \mathrm{mg} / \mathrm{l}$, respectively. The patient was scheduled for elective PPPD. During the procedure, both the bile and pancreatic necrotic tissue were sampled and sent for microbiological investigation. In the postoperative period, the pancreatic fistula grade was scored according to the International Study Group on Pancreatic Fistula [7].

The course of the operation was uneventful, with no need for blood transfusion (blood loss $400 \mathrm{ml}$ ). Due to technical difficulties associated with the presence of pancreatic inflammation and focal necrosis, the procedure duration was $305 \mathrm{~min}$. Both from the bile and pancreatic necrosis samples collected intraoperatively, Escherichia coli was microbiologically cultured. After the PPPD, the patient spent 5 days in the ICU, being mechanically ventilated only on the $1^{\text {st }}$ postoperative day (POD 1). On POD 2, elevation of serum amylase up to $188 \mathrm{IU} / \mathrm{l}$ was observed, which returned to a normal value (31 IU/I) on POD 3. Mild superficial wound infection was noted on POD 5, and positive culture with Enterococcus faecalis from the wound discharge was identified. On POD 7, elevation of serum CRP level up to $159.8 \mathrm{mg} / \mathrm{l}$, together with collection of less than $10 \mathrm{ml}$ of amylase rich fluid from the abdominal drain, was observed. The postoperative grade A pancreatic fistula was recognised and treated medically, with no substantial prolongation of hospital stay. The patient was discharged from hospital on the $20^{\text {th }}$ POD in good clinical condition, fully recovered, on a regular diet. Pathological 
findings revealed stage II ampullary carcinoma (pT3NOMO; microscopically radical resection) with multiple foci of (infected) pancreatic necrosis. Four weeks after primary operation adjuvant chemotherapy was implemented in the regimen: gemcitabine $1000 \mathrm{mg} / \mathrm{m}^{2}$ with cisplatin $50 \mathrm{mg} / \mathrm{m}^{2}$, every 28 days, with good overall tolerance. Local relapse was discovered in September 2009, giving the DFS of 27 months. The patient was enrolled in a chemotherapy regimen of gemcitabine in monotherapy (intravenously in the dose $1000 \mathrm{mg} / \mathrm{m}^{2}$ day 1,8 and 15; repeated every 28 days). Treatment was continued without severe toxicity symptoms for 10 months, including erlotinib for the last 2 courses of chemotherapy. Because of disease progression (multiple liver metastases and ascites), the treatment schedule was changed to the LFP regimen: calcium folinate $20 \mathrm{mg} / \mathrm{m}^{2}$, fluorouracil $300 \mathrm{mg} / \mathrm{m}^{2}$, cisplatin $20 \mathrm{mg} / \mathrm{m}^{2}$ intravenous infusion on days 1-5, given every 28 days, from August to October 2010. Then, due to poor tolerance of chemotherapy and further disease progression, chemical treatment was completed. The patient died 44 months after primary surgery.

\section{Discussion}

Post-stenting complications, including pancreatitis, develop in $24 \%$ of patients with ampullary cancer [8]. About two thirds of patients after placement of a plastic endobiliary stent may experience postoperative complications following PD [9]. A positive intraoperative bile culture is associated with higher morbidity and mortality rates following PD, and a positive culture in patients with preoperative biliary stenting is related to stent complications and duration of stenting [8]. Therefore, it appears prudent to delay PD for 6 weeks or more in patients who develop complications after stenting, unless serious pancreatitis develops that may considerably influence the surgical management.

Since the 1980s, severe necrotizing pancreatitis has been regarded as a relative contraindication to perform elective pancreaticoduodenectomy $[6,10]$. The current report shows that pancreatic necrosis does not preclude delayed PD, especially in a patient with ampullary carcinoma.

Metal stents should be considered for patients with surgically resectable periampullary cancer, since they provide a longer patency rate, fewer ERCP sessions, and fewer episodes of cholangitis without adding any perioperative complications, especially if surgery is not immediately planned $[11,12]$.

Results of the recent multicentre, randomized trial constituted a milestone in assessing the merits of preoperative biliary drainage [13]. No advantage and a significantly higher rate of serious postoperative complica- tions in patients undergoing endoscopic stenting before surgery was found in jaundiced patient periampullary malignancies [13]. Although only scattered data are available on early outcome after PD following severe post-ERCP pancreatitis [14], there are no reports on late outcome. It seems that preoperative biliary drainage and the delay in surgery do not adversely affect late outcome, with median survival time for resected periampullary adenocarcinoma of 44.7 months [15]. However, the occurrence of complications related to preoperative biliary drainage or surgery was found to be significantly associated with worse survival [15].

\section{Conclusions}

Pancreaticoduodenectomy can be performed after severe acute necrotizing pancreatitis caused by preoperative biliary stenting, provided adequate timing of surgery is ensured, albeit with the risk of postoperative complications. Even severe post-ERCP pancreatitis should not be regarded as a contraindication for curative $P D$, especially in patients with periampullary adenocarcinoma, since long-term survival can be achieved.

\section{References}

1. Mallery JS, Baron TH, Dominitz JA, et al Standards of Practice Committee. American Society for Gastrointestinal Endoscopy. Complications of ERCP. Gastrointest Endosc 2003; 57: 633-8.

2. Freeman ML, DiSario JA, Nelson DB, et al. Risk factors for postERCP pancreatitis: a prospective, multicenter study. Gastrointest Endosc 2001; 54: 425-34.

3. Yeo CJ, Cameron JL, Sohn TA, et al. Six hundred fifty consecutive pancreaticoduodenectomies in the 1990s: pathology, complications and outcomes. Ann Surg 1997; 226: 248-57.

4. Winter JM, Cameron JL, Campbell KA, et al. 1423 pancreaticoduodenectomies for pancreatic cancer: a single-institution experience. J Gastrointest Surg 2006; 10: 1199-210.

5. van Geenen RC, van Gulik TM, Offerhaus GJ, et al. Survival after pancreaticoduodenectomy for periampullary adenocarcinoma: an update. Eur J Surg Oncol 2001; 27: 549-57.

6. Uhl W, Warshaw A, Imrie C, et al. International Association of Pancreatology. IAP Guidelines for the Surgical Management of Acute Pancreatitis. Pancreatology 2002; 2: 565-73.

7. Bassi C, Dervenis C, Butturini G, et al. International Study Group on Pancreatic Fistula Definition. Postoperative pancreatic fistula: an International Study Group (ISGPF) definition. Surgery 2005; 138: 8-13.

8. Jagannath P, Dhir V, Shrikhande S, et al. Effect of preoperative biliary stenting on immediate outcome after pancreaticoduodenectomy. Br J Surg 2005; 92: 356-61.

9. Mullen JT, Lee JH, Gomez HF, et al. Pancreaticoduodenectomy after placement of endobiliary metal stents. J Gastrointest Surg 2005; 9: 1094-105.

10. Nordback $\mathrm{IH}$, Auvinen OA. Long-term results after pancreas resection for acute necrotizing pancreatitis. Br J Surg 1985; 72 : 687-9. 
11. Wasan SM, Ross WA, Staerkel GA, Lee JH. Use of expandable metallic biliary stents in resectable pancreatic cancer. Am J Gastroenterol 2005; 100: 2056-61.

12. Lawrence C, Howell DA, Conklin DE, et al. Delayed pancreaticoduodenectomy for cancer patients with prior ERCP-placed, nonforeshortening, self-expanding metal stents: a positive outcome. Gastrointest Endosc 2006; 63: 804-7.

13. van der Gaag NA, Rauws E, van Eijck C, et al. Preoperative biliary dreinage for cancer of the head of the pancreas. $N$ Engl J Med 2010; 362: 129-37.

14. Erkan M, Kleeff J, Reiser C, et al. Preoperative acute pancreatitis in periampullary tumors: implications for surgical management. Digestion 2007; 75: 165-71.

15. Eshuis WJ, van der Gaag NA, Rauws EA, et al. Therapeutic delay and survival after surgery for cancer of the pancreatic head with or without preoperative biliary drainage. Ann Surg 2010; 252: $840-9$ 